\title{
Simulasi Daya Harmonik berbasis Transformasi Wavelet dengan Matlab
}

\author{
Ulul Ilmi \\ Program Studi Teknik Elektro \\ Universitas Islam Lamongan \\ email : $\underline{\text { ululilmi@unisla.ac.id }}$
}

\author{
Zainal Abidin \\ Program Studi Teknik Elektro \\ Universitas Islam Lamongan \\ email : zainalabidin@unisla.ac.id
}

\begin{abstract}
Abstrak
Kemajuan teknologi aplikasi elektronika daya, polusi harmonik pada jaringan sistem tenaga listrik meningkat secara serius, berdampak serius pada jaringan suplai energi dan peralatan. Dalam diskusi ini, penulis mempelajari karakteristik harmonik, analisis metode deteksi harmonik menggunakan algoritma wavelet dengan Matlab.

Hasil dari simulasi menunjukkan bahwa dengan transformasi wavelet dapat mengkomposisi komponen harmonik yang menetap dalam sistem sesuai dengan kebutuhan.
\end{abstract}

\section{Kata kunci : harmonik, wavelet, Matlab}

\section{PENDAHULUAN}

Deteksi harmonik dan kontrol harmonik merupakan bahasan yang penting dalam sistem tenaga. Transformasi Fourier (FT) merupakan metode utama dari analisis harmonik. Metode ini sederhana dan efektif, tetapi memiliki syarat yang rumit dari jumlah sampel point sinyal analisis. Ketika sinyal dianalisis dalam kondisi tidak stabil, frekuensi fundamental mengalami deviasi, sampel sinkron akan sulit dicapai, saat itu transformasi Fourier akan menimbulkan efek penghalang, spektrum bocor dan lainya. Transformasi diskrit wavelet memiliki fungsi melokalisasi waktu frekuensi, biasanya digunakan untuk menganalisis kualitas daya transient.

Analisis transformasi diskrit wavelet juga dapat digunakan pada analisis sinyal tunggal. Topik diskusi ini membahas analisis algoritma wavelet berbasis paket transformasi wavelet dengan Matlab, yang dapat menampilkan divisi keseragaman dari sinyal frekuensi. Dengan penyeleksian kesesuaian pohon wavelet, gelombang frekuensi berada pada titik tengah wavelet, dan mengurangi kebocoran harmonik.

\section{METODOLOGI}

Metodologi dilakukan dengan membandingkan sinyal awal (asli) kemudian dilakukan algoritma transformasi wavelet dengan Matlab. Hasil dekomposisi wavelet menunjukkan penguatan image hasil dari sinyal asli. Hasil dekomposisi wavelet kemudian dilakukan analisis.

\section{Dekomposisi Transformasi Paket Wavelet}

S. Mallet dan Y. Meyer mengusulkan algoritma cepat struktur menara yang diusulkan oleh orthogonal transformasi wavelet, yang disebut algoritma Mallet, dengan menggunakan analisis multiresolusi dan teori penyaringan numerik.Transformasi paket wavelet menyediakan metode analisis yang lebih canggih untuk sinyal, yang membagi pita frekuensi menjadi beberapa lapisan. Bagian frekuensi tinggi yang tidak dibagi dalam analisis multiresolusi dapat didekomposisi lebih lanjut dan dapat didekomposisi sesuai dengan karakteristik sinyal yang dianalisis. Pilih secara adaptif yang sesuai pita frekuensi untuk mencocokkan spektrum sinyal, sehingga meningkatkan dekomposisi jumlah frekuensiwaktu. Oleh karena itu, transformasi paket wavelet memiliki nilai aplikasi yang lebih luas. Misalnya, wavelet packet transform digunakan untuk menguraikan sinyal dengan paket wavelet tiga layer. Representasi grafik ditunjukkan pada Gambar 1. Dalam gambar, H mewakili bagian frekuensi tinggi yang diperoleh oleh masingmasing dekomposisi, dan $\mathrm{L}$ adalah bagian frekuensi rendah yang diperoleh oleh masingmasing dekomposisi. 


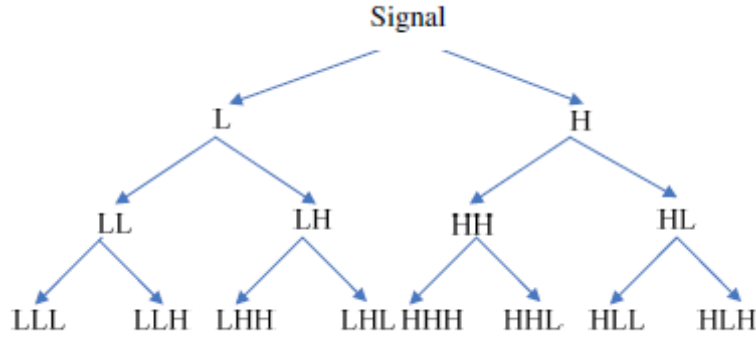

\section{Gambar 1. Tiga layer pohon dekomposisi wavelet dari sinyal}

\section{Prinsip Deteksi Arus Harmonik dengan Transformasi Paket Wavelet}

Struktur sistem deteksi arus harmonik berdasarkan transformasi paket wavelet ditunjukkan pada

Gambar 2. Secara umum, sinyal dipisahkan oleh dekomposisi dan rekonstruksi paket wavelet.

Akhirnya, sinyal yang direkonstruksi dan sinyal harmonik asli dikurangi untuk mendapatkan

sinyal kompensasi harmonik. Kemudian sinyal kompensasi harmonik diinjeksikan ke dalam jaringan, penindasan sinyal harmonik dapat direalisasikan untuk menyelesaikan deteksi karakteristik harmonik sistem tenaga.

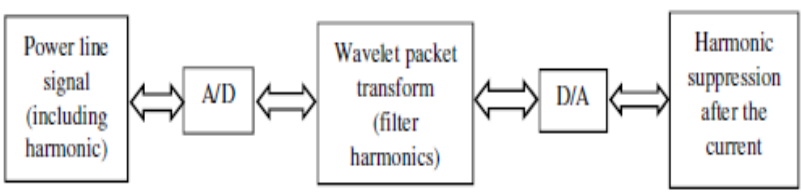

\section{Gambar 2. Struktur proses deteksi arus harmonik dengan wavelet}

\section{HASIL DAN ANALISIS}

Dalam jaringan distribusi , arus harmonik terutama berbentuk $2 n+1(n=1,2, \ldots \ldots)$ dan harmonik bentuk lain, dalam analisis harmonik sampel frekuensi $6400 \mathrm{~Hz}$ digunakan sebagai sampel sinyal, dan 1024 poin sampel (8 siklus) diambil untuk analisis harmonik.

Bentuk sinyal asli dan kurva amplitudo frekuensi dapat ditunjukkan pada gambar 3 berikut :
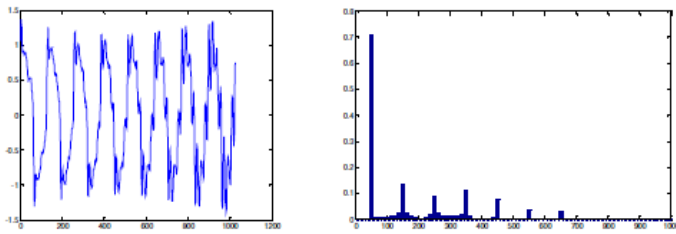

(a).Gambar sinyal asli

(b) karakteristik amplitudo frekuensi

Dalam sebuah kasus harmonik, jika nilai $\mathrm{H}$, $\mathrm{fBm}$ menunjukkan untuk $\mathrm{H}>0,5$, jarak-panjang dan untuk $\mathrm{H}<0,5$, jarak pendek atau menengah. Jika situasi disimulasikan menggunakan file $\mathrm{M}$ wfbm, maka dapat dilakukan coding sebagai berikut :

\% Generate $\mathrm{fBm}$ for $\mathrm{H}=0.3$ and $\mathrm{H}=0.7$

$\%$ Initialize the randn generator

randn('state',1)

$\%$ Set the parameter $\mathrm{H}$ and the sample length

$\mathrm{H}=0.3 ; \lg =1000$;

$\%$ Generate and plot wavelet-based $\mathrm{fBm}$ for $\mathrm{H}=$ 0.3

fBm03 = wfbm $(\mathrm{H}$, lg, 'plot');

maka hasil program :

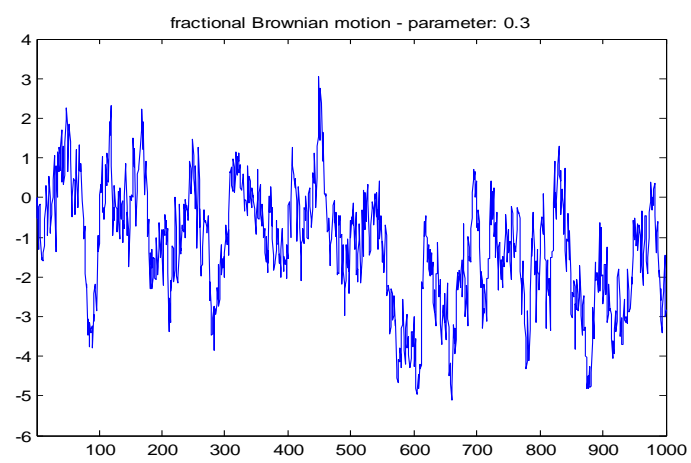

\section{Gambar 2. Fractional motion-parameter 0.3}

$\%$ Reset randn generator and parameter $\mathrm{H}$ randn('state',1); $\mathrm{H}=0.7$;

$\%$ Generate and plot wavelet-based $\mathrm{fBm}$ for $\mathrm{H}=$ 0.7

fBm07 = wfbm $\left(\mathrm{H}, \mathrm{lg}\right.$, 'plot' $^{\prime}$;

$\%$ The last step is equivalent to

$\%$ Define wavelet and level of decomposition

$\% \mathrm{w}=$ 'db10'; ns = 6;

$\%$ Generate

$\%$ fBm07 = wfbm(H,lg,'plot',w,ns);

Setelah dilakukan dekomposisi dengan wavelet maka gambar berubah menjadi gambar 3 berikut :

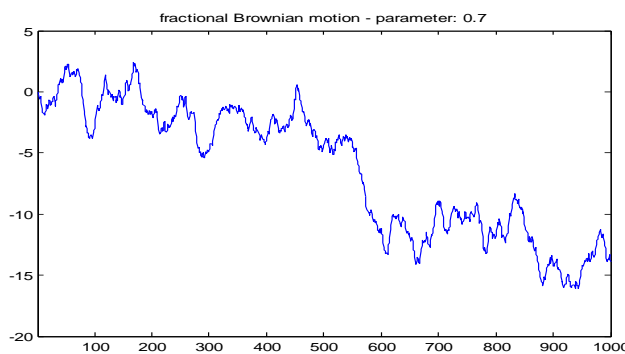




\section{Gambar 3. Fraktional dengan wavelet}

Seperti yang digambarkan pada gambar 4 melalui transformasi fourier spektrum analisis, kita dapat melihat setelah 5 layer dekomposisi db10, kita dapat mencapai frekuensi fundamental $50 \mathrm{~Hz}$.

Transformasi wavelet dapat memisahkan gelombang harmonik fundamental ke 3 , ke 5 , ke 7 , ke 9 , ke 11, dan ke 13 .
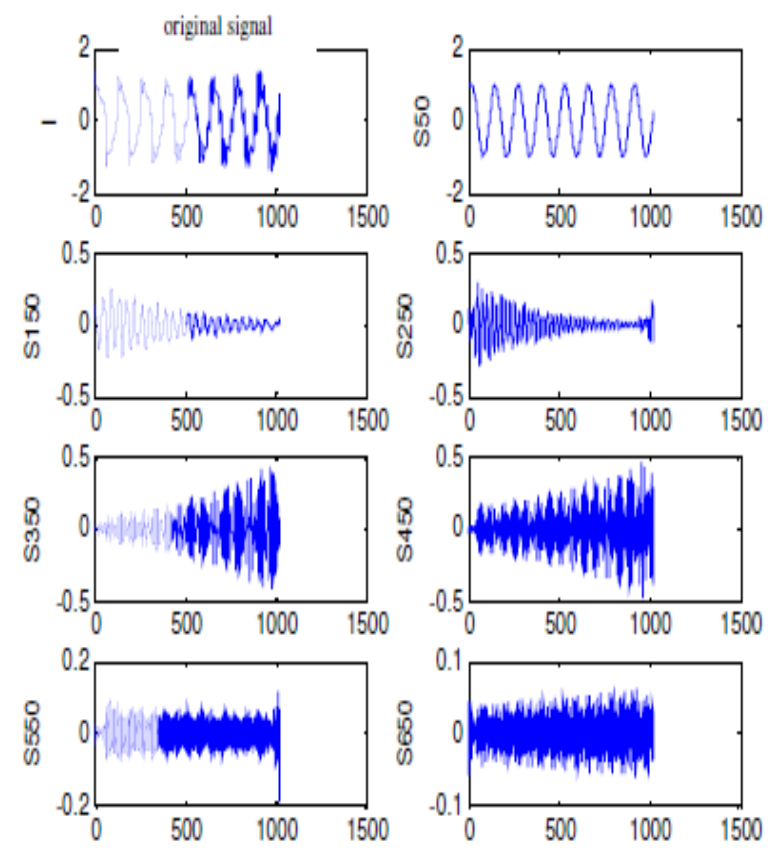

Gambar 4. Karakteristik Kurva amplitudo frekuensi setelah rekontruksi dengan wavelet

Analisis spektrum frekuensi sinyal setelah deduksi gelombang fundamental, akan didapatkan perubahan sinyal dasar tidak $50 \mathrm{~Hz}$ yang utama terdiri dari harmonik ke 3 , ke 5 , ke 7 , ke-9, ke-11, ke-13.

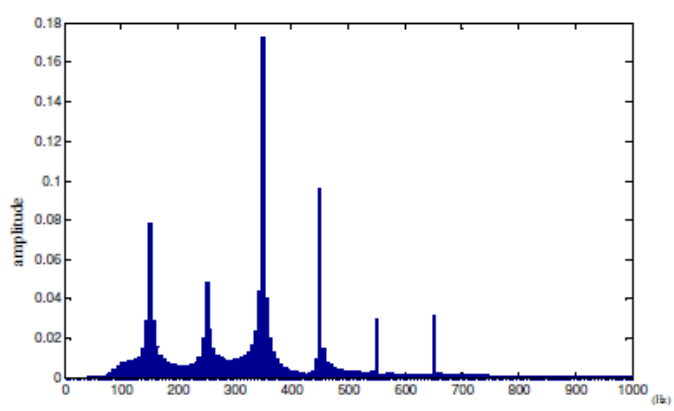

\section{Gambar 5. Karakteristik amplitudo frekuensi setelah rekontruksi dan deduksi sinyal frekuensi}

\section{PENUTUP \\ Simpulan}

Melalui hasil simulasi, dapat dinyatakan bahwa paket transformasi wavelet memiliki karakteristik lokalisir waktu-frekuensi, dimana ekstraksi secara simultan karakteristik sinyal waktu-frekuensi, which can simultaneously extract the time-frequency dapat secara akurat memisahkan gelombang fundamental pada sinyal harmonik.

Transformasi wavelet dapat memisahkan sinyal harmonik sesuai dengan kebutuhan. . Hal ini merupakan peletakkan dasar untuk kompensasi harmonik dari jaringan listrik dan menyediakan metode analisis yang lebih sederhana dan efektif dalam analisis kualitas daya.

\section{PUSTAKA}

[1] Liu Y, Jiang B, Wang C, et al. Power system harmonic analysis based on windowed FFT and wavelet transform[C]. The International Conference on Electric Utility Deregulation and Restructuring and Power Technologies. 2011:225-228.

[2] Barros J, Diego R I. Analysis of Harmonics in Power Systems Using the Wavelet-Packet Transform[C]. IEEE Instrumentation \& Measurement Technology Conference. 2008:63-69.

[3] Zhang T. Harmonic Analysis in Power System Based on Harmonic Wavelet[J]. Modern Electronics Technique, 2009.

[4] Kumar G S, Sarma D V S, Venkatesh C. Wavelet transform based harmonic analysis and real power measurement[C] Power Electronics (IICPE), 2010 India International Conference on. IEEE, 2011:1-6.

[5] Zhang T. Harmonic Analysis in Power System Based on Harmonic Wavelet [J]. Modern Electronics Technique, 2009.

[6] Wu S, Wan J, Sun G, et al. Suppression of inverter output harmonic [C]. Computer Science and Information Technology (ICCSIT). 2010 3rd IEEE International Conference on. IEEE, 2010:434-437. 
